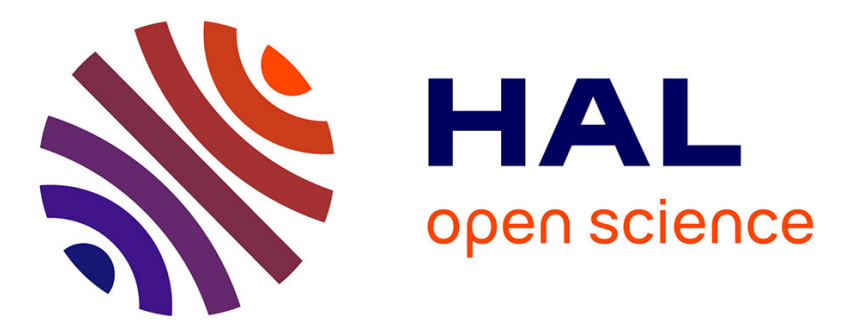

\title{
ITS-based comparison of endophytic mycota in twigs of native Populus nigra and cultivated P. x euramericana (cv. I-214) stands in Northern Spain
}

Martín-García, Michael Müller, Julio Diez

\section{- To cite this version:}

Martín-García, Michael Müller, Julio Diez. ITS-based comparison of endophytic mycota in twigs of native Populus nigra and cultivated P. x euramericana (cv. I-214) stands in Northern Spain. Annals of Forest Science, 2012, 69 (1), pp.49-57. 10.1007/s13595-011-0129-4 . hal-00930699

\section{HAL Id: hal-00930699 \\ https://hal.science/hal-00930699}

Submitted on 1 Jan 2012

HAL is a multi-disciplinary open access archive for the deposit and dissemination of scientific research documents, whether they are published or not. The documents may come from teaching and research institutions in France or abroad, or from public or private research centers.
L'archive ouverte pluridisciplinaire HAL, est destinée au dépôt et à la diffusion de documents scientifiques de niveau recherche, publiés ou non, émanant des établissements d'enseignement et de recherche français ou étrangers, des laboratoires publics ou privés. 


\title{
ITS-based comparison of endophytic mycota in twigs of native Populus nigra and cultivated $P . x$ euramericana (cv. I-214) stands in Northern Spain
}

\author{
Jorge Martín-García • Michael M. Müller • \\ Julio Javier Diez
}

Received: 15 July 2011 / Accepted: 9 August 2011 / Published online: 31 August 2011

(C) INRA and Springer Science+Business Media B.V. 2011

\begin{abstract}
- Context The European black poplar (Populus nigra) is considered one of the most seriously endangered indigenous tree species. However, the total area covered by monoclonal plantations of hybrid poplar is growing, because of the high profitability of these trees.

- Aim The aim of this study is to describe and compare the endophytic mycota in twigs from native poplar ( $P$. nigra) and hybrid poplar plantations ( $P$. x euramericana clone I-214).

- Methods Twig endophytes were isolated from three native and three hybrid poplar stands in Palencia (N. Spain). Three

\footnotetext{
Handling Editor: Erwin Dreyer

Contribution of the co-authors Jorge Martín-García: designing the experiment, recollecting samples, working in laboratory (sample treatment and molecular identification of isolates), running the data analysis and writing the paper.

Michael M. Müller: designing the experiment, reviewing the paper and supervising the work.

Julio Javier Diez: designing the experiment, reviewing the paper and coordinating the research project
}

J. Martín-García · J. J. Diez

Sustainable Forest Management Research Institute,

University of Valladolid - INIA,

Avenida Madrid, 57,

34004 Palencia, Spain

J. J. Diez

e-mail: jdcasero@pvs.uva.es

\section{J. Martín-García $(\square)$}

Forestry Engineering, University of Extremadura,

Avenida Virgen del Puerto 2,

10600 Plasencia, Spain

e-mail: jorgemg@pvs.uva.es

\section{M. Müller}

The Finnish Forest Research Institute,

P.O. Box 18, 01301 Vantaa, Finland

e-mail: michael.mueller@metla.fi trees were chosen at random within each stand sampled. Isolates were identified according to sequences of the internal transcribed spacer region of their rDNA. The study focused on dominant species.

- Results A total of 13 species were found. Six species originated from P. nigra only (Stemphylium vesicarium, Alternaria spp., Aureobasidium pullulans, Fimetariella rabenhorstii, Plagiostoma fraxini and Cryptodiaporthe salicella) and four from P. x euramericana only (Cytospora chrysosperma, Athelia bombacina, Biscogniauxia mediterranea and Unidentified sp. 1), whereas three were found on both types of trees (Lewia infectoria, Alternaria alternata and Epicoccum nigrum).

- Conclusion The results show that the endophyte community on poplar twigs differs between native and hybrid poplars

Keywords Native $\cdot$ Hybrid $\cdot$ Poplar $\cdot$ Endophyte $\cdot$ Twig

\section{Introduction}

Populus nigra L., the European black poplar, is a dioecious, heliophilous, pioneer tree species in alluvial forests and considered a keystone species in floodplain forests in Europe. Although P. nigra is widely distributed throughout Europe, it is one of the most seriously endangered indigenous forest tree species and is threatened by three main factors. Firstly, hydraulic structures that regulate flood periods have been modified to favour hardwood species. Secondly, P. nigra has been replaced by hybrid poplars because of the higher profitability of the latter. Finally, gene introgression from cultivated poplars is a potential threat to P. nigra, as few clones are extensively cultivated, and they contribute to a large proportion of pollen and seed pools (Lefèvre et al. 1998; Smulders et al. 2008). 
Plantations of hybrid poplar are of great interest in Spain, because of their economic value as a source of plywood. The profits associated with cultivated poplar reach between 1,200 and 2,400 $€ /$ ha/year for highly favourable sites (Díaz and Romero 2001). Single plantations are monoclonal and although several hybrids are used in Spain, Populus $x$ euramericana (Dode) Guinier clone I-214 $(P$. deltoides Marsh. $+\times P$. nigra L. đ) is the most common. It covers about $70 \%$ of the total area covered by poplar plantations (Fernández and Hernanz 2004).

A current goal of national and regional forest policy is to increase the area occupied by poplar plantations. Castilla and León, the region with the largest area covered by poplar plantations in Spain (ca. two thirds of the total), has drawn up a first draft of a "strategy for poplar growing", the main objective of which is to double the area covered by poplar plantations in the next two decades.

In light of this, a trade-off between economic benefits and the maintenance of biological and functional diversity in poplars is necessary.

Decreased cover by $P$. nigra through replacement with $P$ $x$ euramericana or a possible drastic decrease in genetic variation through intensive introgression would probably also cause indirect effects on other organisms associated with $P$. nigra. However, while great importance is given to macroscopic life forms, little attention is paid to the potential consequences of the loss of microbial diversity (Strobel 2003). As plants are known to harbour hostspecific microorganisms, disappearance of a plant species also results in the disappearance of these microorganisms. This is not desirable because e.g. the production of novel and biologically active secondary metabolites is common among fungal endophytes; therefore, this group of fungi is a potential source of new products for pharmaceutical and agrochemical industries. Transformation of native poplar stands into monoclonal plantations or hybrid zones appears to alter pre-existing fungal communities (Whitham et al. 1999). A trend towards decreased genetic variation in forestry may increase the phytosanitary risk because monoclonal forests are known to be more vulnerable to diseases than native forests (Pinon 1984).

Many definitions of the term endophyte have been used in the scientific literature. The term is often used to refer to fungi able to infect their hosts without causing visible disease symptoms (Schulz and Boyle 2005). In the present study, the term endophyte is used to refer to fungi isolated from healthy-looking surface-sterilized plant samples.

The aim of this study was to describe and compare the endophytic mycota on twigs of native poplar ( $P$. nigra) and hybrid poplar trees ( $P$. x euramericana clone I-214) in Spain.

\section{Material and methods}

\subsection{Description of the study site and sampling}

Three poplar plantations of clone I-214 and three native poplar stands (P. nigra) were chosen for study, in Palencia (N. Spain). The altitude, edaphic and climatic characteristics of all stands were similar (Table 1), and stands were situated at a maximum distance of $60 \mathrm{~km}$ from each other (Fig. 1). The poplar plantations (P. x euramericana, clone I214) were 10-year-old monoclonal plantations established in 1995 by the Government of the Castile and Leon, whereas stands of native poplar ( $P$. nigra) exist as remnants patches.

In October 2006, three trees were randomly chosen within each sampling stand. Native poplars of breast height diameter $(10-20 \mathrm{~cm})$ similar to those of the hybrid poplar sampling sites were selected for sampling. Four healthy branches from four horizontal sectors of the upper third of the canopy of each tree were collected. The branches were stored at $4^{\circ} \mathrm{C}$ and processed within $24 \mathrm{~h}$.

\subsection{Sample treatment}

Four pieces of twig (1 year old, diam. $0.5 \mathrm{~cm}$, length $5 \mathrm{~cm}$ ) were cut from each branch and surface sterilized by: shaking in $70 \%$ ethanol $(v / v)$ for $1 \mathrm{~min}$, followed by shaking in $4 \%$ sodium hypochlorite $(v / v)$ for $4 \mathrm{~min}$, thereafter shaking in $70 \%$ ethanol $(v / v)$ for $1 \mathrm{~min}$ and finally dipping for a few seconds in $70 \%$ ethanol $(v / v)$. The samples were then dried for 1-5 $\mathrm{min}$ in a sterile laminar flow cabinet in open Petri dishes. Each twig piece was split into four longitudinal segments and placed in serial order on Petri dishes containing "potato dextrose agar" (PDA) medium (Scharlau product, Barcelona, Spain, prepared

Table 1 Edaphic and climatic characteristics of the stands

\begin{tabular}{lrccc}
\hline Stand & $\begin{array}{l}\text { Altitude } \\
(\mathrm{m})\end{array}$ & $\begin{array}{l}\text { Annual } \\
\text { precipitation }^{\mathrm{a}}(\mathrm{mm})\end{array}$ & $\begin{array}{l}\text { Mean annual } \\
\text { temperature }^{\mathrm{a}}\left({ }^{\circ} \mathrm{C}\right)\end{array}$ & Soil type $^{\mathrm{b}}$ \\
\hline Pn 1 & 800 & 429 & 11 & Alluvial \\
Pn 2 & 800 & 467 & 11 & Alluvial \\
Pn 3 & 996 & 637 & 10 & Alluvial \\
Px 1 & 900 & 596 & 11 & Alluvial \\
Px 2 & 1000 & 687 & 10 & $\begin{array}{c}\text { Alluvial } \\
\text { Fluvial } \\
\text { terraces }\end{array}$ \\
Px 3 & 859 & 535 & 11 & \\
& & & &
\end{tabular}

Px P. x euramericana, Pn P. nigra

a According to "Atlas Climático Digital de la Península Ibérica" (Ninyerola et al. 2005)

b According to "Mapa geológico y Minero de Castilla y León" (SIEMCALSA 1997) 
a

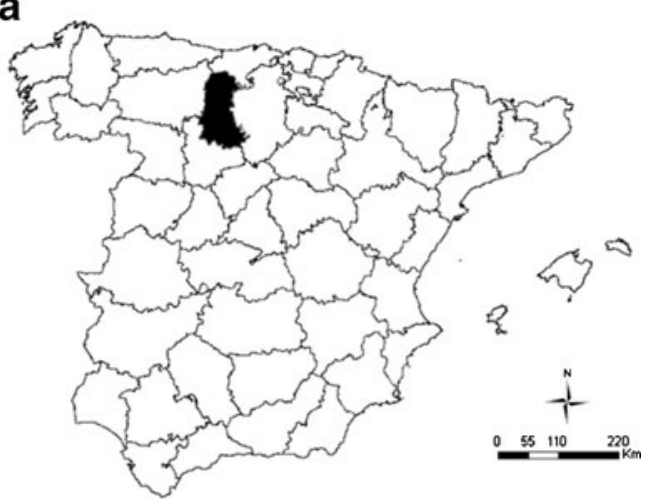

b

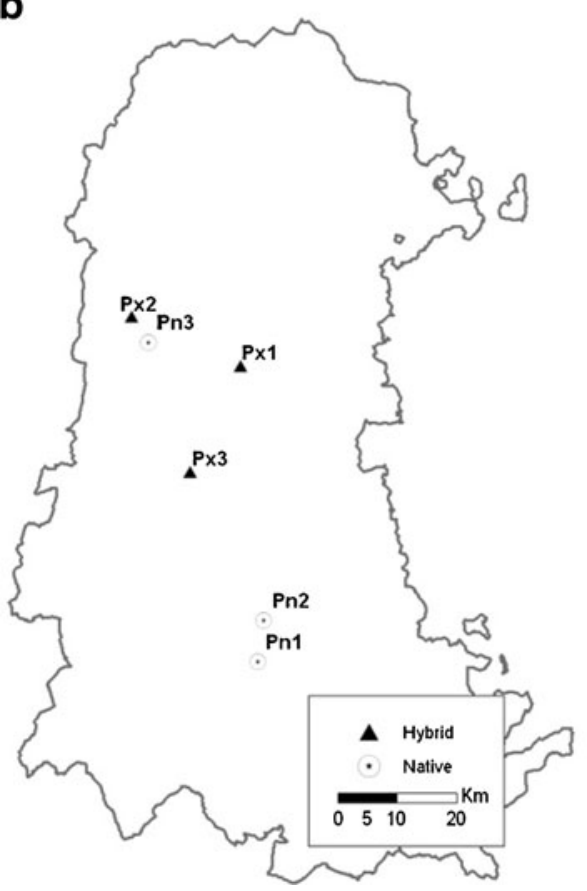

Fig. 1 Geographical location of the six sites surveyed. a Geographic location in Spain; b geographic location in the province of Palencia

according to the manufacturer's instructions). The plates were sealed with Parafilm ${ }^{\circledR}$ and incubated in darkness at $22^{\circ} \mathrm{C}$ for 3 weeks. One outgrowing colony from each branch was chosen according to the serial order of the Petri dish and transferred to a new Petri dish with PDA medium. Four isolates per sampled tree were obtained to provide 36 isolates per treatment/species (i.e. four isolates/tree $\times$ three trees/stand $\times$ three stands $=36$ ), with two types of poplar (i.e. a total of 72 isolates).

Obviously, the total diversity of endophytes cannot be measured and quantified comprehensively so that we decided to focus on dominant species to achieve a tradeoff between ecological rigour and economic efficiency. A sample size of 36 isolates per population allows detection (at $p>0.95$ ) of a species occurring with a frequency of at least $0.08\left[p=1-(1-f)^{n}\right.$, where $f=$ frequency and $n=$ sample size].

\subsection{Molecular identification of isolates}

To obtain agar-free mycelial samples for DNA isolation, the isolates were cultivated on agar plates and covered with Cellophane (Surface Specialities, Wigton Cumbria, UK). MOS agar was used to allow fast growth (Müller et al. 1994). Total DNA was isolated according to Vainio et al. (1998). The protocols included cell disruption with quartz sand and a FastPrep ${ }^{\circledR}$ cell disrupter (Qbiogene, Inc., Cedex, France) for $2 \times 20 \mathrm{~s}$ at $4 \mathrm{~ms}^{-1}$, two phenol/chloroform/ isoamyl alcohol (50:49:1) and one chloroform/isoamyl alcohol (24:1) extraction, precipitation with polyethylene glycol and drying. DNA was resuspended in $50 \mu \mathrm{l}$ of TEbuffer ( $\mathrm{pH} 8.0$ ), containing $10 \mathrm{mM}$ Tris- $\mathrm{HCl}$ and $1 \mathrm{mM}$ ethylenediaminetetraacetic acid. This procedure was adequate for most isolates, although for some isolates, up to four extractions in phenol/chloroform/isoamyl alcohol (50:49:1) were required to remove visible pigment from the extract.

The internal transcribed spacer (ITS) region of the rDNA was amplified with primers ITS1-F (Gardes and Bruns 1993) and ITS4 (White et al. 1990). All amplifications were performed according to White et al. (1990) and Vainio and Hantula (2000).

PCR products were purified with the High Pure PCR Product Purification Kit (Roche, Mannheim, Germany), according to the manufacturer's instructions. The sequences were determined in an automated sequencing apparatus (LiCor Global Edition IR $^{2}$ system; Li-Cor Inc., Lincoln, NE, USA), by following the manufacturer's instructions. DNA fragments were sequenced in both directions at the same time. Finally, the sequences were aligned with LI-COR software (ALIGN IR ver. 2.0). Consensus sequences were identified by comparing them with sequences deposited in GenBank (NCBI) database, by means of the BLAST algorithm. The isolates were named according to the best GenBank match if at least $97 \%$ matched at least $401 \mathrm{bp}$.

Sequences generated in this study have been submitted to GenBank under accession number FR648327-FR648398.

\subsection{Statistical analyses}

Differences in species richness and diversity between native ( $P$. nigra) and hybrid poplars ( $P . x$ euramericana) were evaluated by Mann-Whitney $U$ tests (nonparametric tests). Diversity was estimated by use of the Shannon index:

$H=-\sum_{i=1}^{S} p_{i} \log p_{i}$ 
where $H$ is the number of species and $p_{i}$ is proportion of the $i$ th species in a sample.

Canonical correspondence analyses (CCA) were carried out to test whether endophyte assemblages were different between native and hybrid poplars. For this, type of poplar was considered as environmental data (nominal variables), and frequency of species was transformed by $\log (x+1)$. The statistical significance was tested by means of a Monte Carlo permutation test with 499 permutations of total inertia.

Univariate analyses were performed with the Statistical 6.0 package (StatSoft 2001) and multivariate analyses with CANOCO 4 (Ter Braak and Šmilauer 2002).

Richness and diversity accumulation curves were developed with EstimateS software, version 8.2 (Colwell 2005).

Phylogenetic and molecular evolutionary analyses were conducted with MEGA, version 4 (Molecular Evolutionary Genetics Analysis) (Tamura et al. 2007).

\section{Results}

At least one isolate was obtained from all twig samples. The ITS sequences obtained varied from 401 to $548 \mathrm{bp}$ in length, including the complete or partial ITS1, complete 5.8 $\mathrm{S}$ ribosomal RNA gene and complete or partial ITS2. Two of the 72 sequences did not provide an accepted match with any sequence in the GenBank ( $\min .97 \%$ similarity of at least $401 \mathrm{bp}$ sequence length). A total of 13 species were found. Nine species originated from $P$. nigra, seven from $P$. $x$ euramericana and three [(Lewia infectoria (Fuckel) M.E. Barr \& E.G. Simmons (anamorph: Alternaria infectoria E. G. Simmons), Alternaria alternata (Fr.) Keissl. and Epicoccum nigrum Link)] were found on both types of trees (Table 2). Although A. alternata was more frequent on P. nigra ( $p<0.03$; Fisher's exact test), it was also found on one hybrid tree.

Species found only on samples of $P$. nigra were: Alternaria spp., Aureobasidium pullulans (de Bary) G. Arnaud, Cryptodiaporthe salicella (Fr.) Petr., Fimetariella rabenhorstii (Niessl) N. Lundq., Plagiostoma fraxini (Redlin $\&$ Stack) Sogonov and Stemphylium vesicarium (Wallr.) E.G. Simmons. On the other hand, Athelia bombacina Pers., Biscogniauxia mediterranea (De Not.) Kuntze, Cytospora chrysosperma (Pers.: Fr.) Fr. (teleomorph: Valsa sordida Nitschke) and an unidentified species were only found on $P$ $x$ euramericana. C. chrysosperma was isolated from seven out of nine hybrid poplar trees sampled; this frequency was significantly higher than the complete absence on $P$. nigra $(p<0.01$, Table 2$)$.

A phylogenetic analysis, based on the ITS sequences (Fig. 2), showed that all clusters including isolates from only one of the two types of poplar stand (e.g. $C$. chrysosperma, A. pullulans and F. rabenhorstii) differed greatly from the next nearby cluster with isolates from the other poplar type. For instance, the mismatch between isolates Pn3_1_2 (C. chrysosperma from hybrid poplar) and Px3_2_1 (C. salicella from P. nigra) of two nearby clusters was $67 \mathrm{bp}$ of a 367-bp long sequence in common (i.e. $18 \%$ ).

Species richness and diversity, as expressed by the Shannon index of isolates from native poplar, were higher than those for isolates obtained from hybrid poplar (Table 2), although the differences were not significant ( $p=0.10$ and $p=0.07$, respectively).

The logarithmic equation provided a good explanation for the richness and diversity accumulation curves (Fig. 3). The logarithmic equations (Fig. 3) predict a low increase in number of species with increasing number of trees sampled. For instance, for native and hybrid poplars, 16 and 12 species, respectively, would have been isolated from a sample of 100 trees, whereas we found nine and seven species from nine trees, respectively.

A CCA showed that fungal assemblages differed according to type of poplar (Fig. 4). The result of the Monte Carlo test, with 499 permutations, was significant $(p<0.01)$, and CCA showed that $17.4 \%$ of the total variation in species data could be explained by type of poplar. An ordination diagram displayed species exclusively isolated from native (Alternaria spp., A. pullulans, C. salicella, F. rabenhorstii, $P$. fraxini and $S$. vesicarium) or hybrid poplar (A. bombacina, B. mediterranea, C. chrysosperma and Unidentified 1). Furthermore, A. alternata, which was isolated from native and hybrid poplar, was more closely associated with native poplars.

\section{Discussion}

The results of the study show that the endophyte community of poplar twigs differs between native P. nigra and clone I-214, as only three out of 13 observed species were found on both poplars and the frequency of two species differed significantly (Table 2). Identification of the isolates in this study is based solely on DNA sequence blast results in GenBank and therefore must be regarded as tentative.

The sampling intensity used in the study is too low to reveal specific endophyte species for $P$. nigra from among species occurring at low frequency. As already mentioned, the present study therefore concentrates on species occurring at high frequencies, i.e. dominant species.

The cumulative curves for species richness and diversity (Fig. 3) show that the number of trees sampled in this study provided a reasonably good indication of twig endophyte richness and diversity of the two types of poplar in the stands under study. The diversity indices would not have 


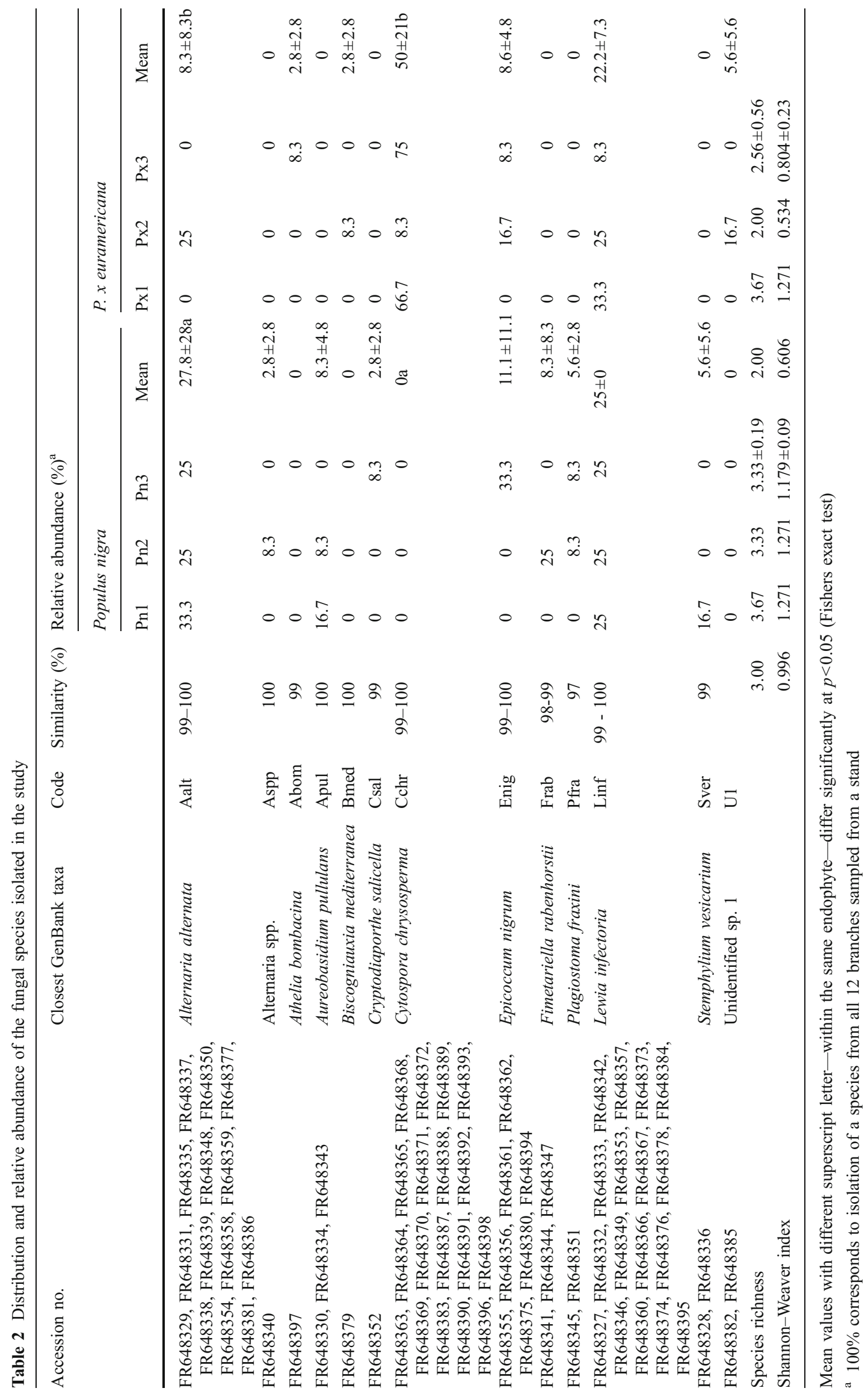


Fig. 2 Neighbour-joining tree generated from ITS sequences of 72 isolates. Codes at the ends of branches correspond to host (Px P. x euramericana or Pn P. nigra), number of stand, number of tree and number of isolate. Accession numbers are shown in brackets

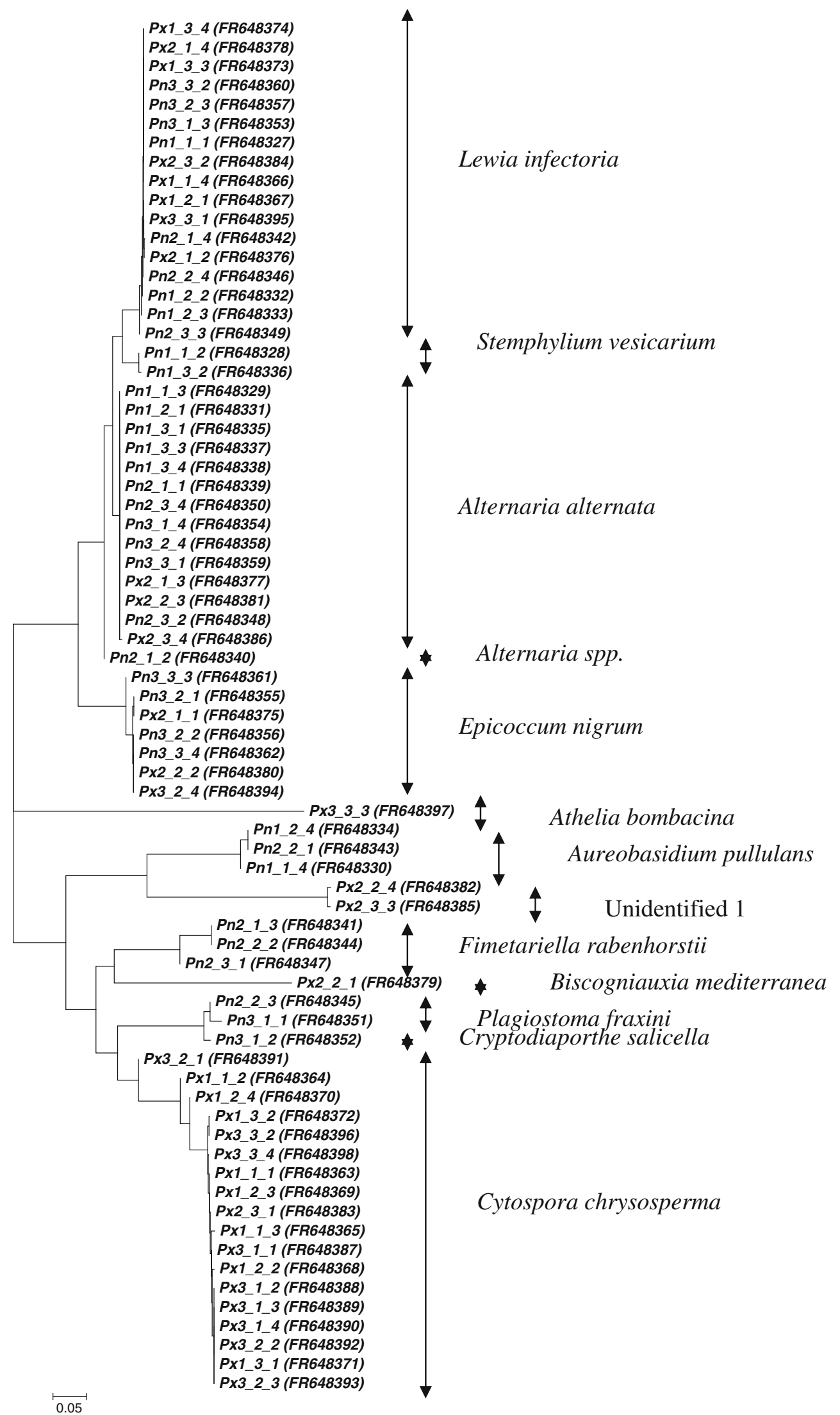




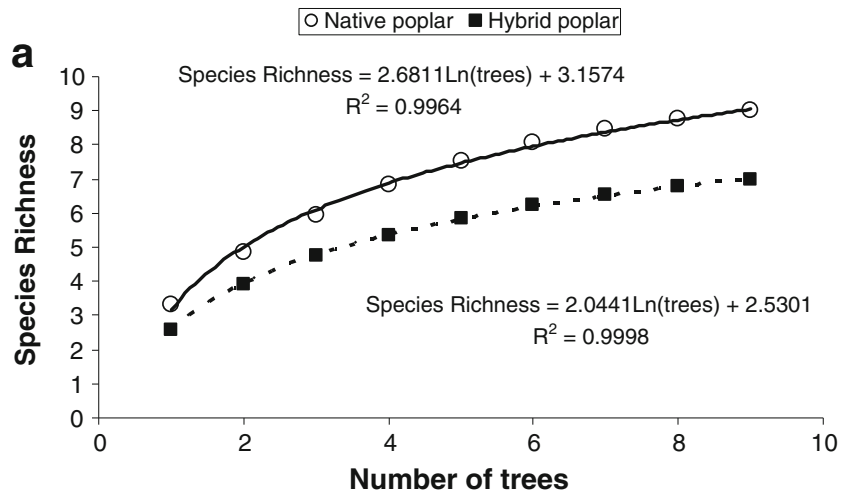

likely that it would have been found on P. x euramericana in this study if a larger number of samples had been examined.

Two of the species found on native poplars (F. rabenhorstii and $S$. vesicarium) have not previously been reported from $P$. x euramericana (Callan 1998; Ginns 1986; Martín-García et al. 2011), Populus tremula (Santamaría and Diez 2005) or genera that share the same forest habitat such as Salix sp. (Petrini and Fisher 1990) and Alnus sp. (Fisher and Petrini 1990). Furthermore, C. salicella appears to be a common species in riparian habitats, since it has been isolated from Salix sp. (Ginns 1986), Alnus sp. (Ginns 1986), Populus tremuloides (Callan 1998; Ginns 1986), P. trichocarpa (Callan 1998; Ginns 1986) and P. canadensis (P. deltoides $x$ nigra $x$ engenei) (Ginns 1986). P. fraxini is apparently not specific to the genera Fraxinus sp. and Chionanthus sp., as earlier suggested (Sogonov et al. 2008).

Species isolated from hybrid poplars, except $A$. bombacina, have previously been isolated from other tree species. Thus,

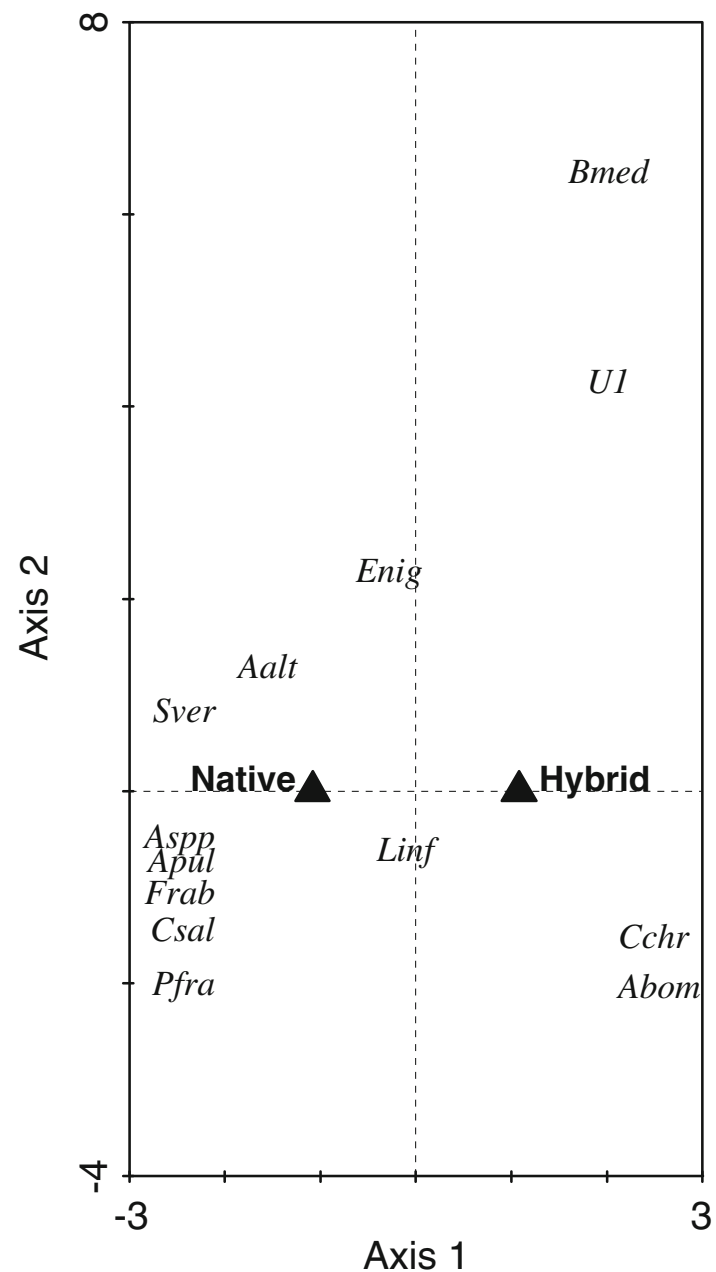

Fig. 3 a Richness and $\mathbf{b}$ diversity accumulation curves for native and hybrid poplars

changed greatly even if many more samples had been processed. A greater number of sample trees would probably have revealed more occasional and rare species but not the predominant specific endophyte species on poplar.

Several most common species found on P. nigra (A. alternata, E. nigrum and $L$. infectoria) were also found on hybrid clone I-214 (Table 2 and Fig. 2), which all can be classified as generalist species (Schulz and Boyle 2005). However, C. chrysosperma, the most common endophyte of clone I-214 was absent from P. nigra.

The community structure of twig endophytes of the native $P$. nigra and clone I-214 differed greatly according to a Monte-Carlo test and are clearly visualized by the canonical correspondence analysis (Fig. 4). This general difference is noteworthy as clone I-214 is a $50 \%$ descendant of $P$. nigra. In previous studies, distinct differences between endophytic communities were found on comparison of different tree species (Fisher and Petrini 1990). Significant differences in the community structure of ectomycorrhizal fungi in various clones of Norway spruce have also been reported (Korkama et al. 2006).

A. pullulans was only isolated from P. nigra, even though it is also considered as a generalist species. This endophyte has previously been isolated from P. x euramericana (clone I-214) (Martín-García et al. 2011), so that it is

Fig. 4 Canonical correspondence analysis ordination biplot (axes 1 and 2) of fungal species and type of poplar. See Table 1 for species abbreviations 
C. chrysosperma was isolated from Populus tremuloides (Callan 1998), P. tremula (Santamaría and Diez 2005), P. balsamifera (Callan 1998), P. trichocarpa (Callan 1998), Populus hybrid (Callan 1998) and Eucalyptus grandis (Bettucci and Alonso 1997). Furthermore, Petrini and Fisher (1990) found Cytospora sp. colonising Salix fragilis. Moreover, B. mediterranea is regarded as a ubiquitous species as it has been isolated from numerous other tree genera (Nungent et al. 2005).

Most of the species detected are probably "true endophytes", as they have not been reported from plant tissues with visible disease symptoms. However, three species $(S$. vesicarium, $C$. chrysosperma and B. mediterranea) can also be regarded as weak pathogens detected during latency. $S$. vesicarium is known as a pathogen able to cause severe damage to pear (Rossi and Pattori 2009) and onion (Aveling and Snyman 1993) amongst other species but has not previously been reported from poplar. B. mediterranea is generally known to occur in healthy living trees as an endophyte, occasionally becoming invasive under water stress conditions (Nungent et al. 2005). C. chrysosperma is known to be a typical weak pathogen of poplars and is widely distributed throughout the northern hemisphere and Australia, although it is able to cause severe damage under certain conditions (Worrall et al. 2008).

The occurrence of $C$. chrysosperma on only hybrid poplars can be explained by the origin of the hybrid poplar seedlings or different susceptibility of the poplar types to this weak pathogen or endophyte. The hybrid poplars in each sampled stand probably originated from cuttings of a single ortet, which may have been infested by Cytospora, and it is therefore possible that all cuttings used in the plantation already carried this fungus as a latent infection. On the other hand, hybrid poplar may be more susceptible than native poplar, because of the hybrid susceptibility pattern (Fritz 1999). It is well known that poplar species and even clones differ in susceptibility to attacks of various fungal species. For instance $P$. trichocarpa is more susceptible to $C$. chrysosperma than $P$. $x$ canadensis (syn. P. $x$ euramericana) (Bloomberg 1962a,b), and Alonso et al. (2000) noted that the susceptibility of $P$. $x$ euramericana to C. chrysosperma varies according to the clone.

P. $x$ euramericana can be considered as a partly exotic species because $P$. deltoides, the other parent species, originates from North America. The hybrid poplar may therefore carry resistance factors (genes), which are new to the fungal flora in Spain. This may explain some of the observed differences in the twig endophyte assemblages between native and hybrid poplars. The hybrid poplar is known to grow considerably faster than the native poplar, which is the main reason for its popularity among foresters. The speed of growth may affect the mycobiota associated with the tree, as shown by Korkama et al. (2006) in studies on the mycorrhizal diversity of various spruce clones. The results of the latter study showed significant differences between the ectomycorrhizal diversity of slow and fast growing Norway spruce clones.

Edaphic, climatic and other site-specific factors are not likely causes of differences in the observed structure of endophyte species on the two poplar types, as the characteristics of all stands were similar.

The present results show that the structure of endophytic species found on P. nigra twigs differed from that found on twigs the hybrid poplar $P x$ euramericana, but that all of the three most common species observed on P. nigra were also found on the hybrid clone. These results should be considered as preliminary findings, and further studies on leaf, wood and root endophytes as well as on mycorrhizal species should be carried out to evaluate the risk of loss of area covered by $P$. nigra through replacement with $P x$ euramericana or a possible drastic decrease in genetic variation through intensive introgression.

Acknowledgements We thank Marja-Leena Santanen and Antonio Sanz for their technical assistance. The authors also thank Leticia Botella for helpful comments on earlier versions of the manuscript. Christine Francis checked the English version and provided generous linguistic advice.

Funding Financial support for this study was provided by the European Union and the Regional Government of Castile and Leon, through the INTERREG IIIB Atlantic Area programme (FORSEE project).

\section{References}

Alonso D, Pajares J, Diez J (2000) Evaluación del poder patogénico de Cytospora chrysosperma en clones de chopo. Boletín de Sanidad Vegetal Plagas 26:415-423

Aveling TAS, Snyman HG (1993) Infection studies of Stemphylium vesicarium on onion leaves. Mycol Res 97:984-988

Bettucci L, Alonso R (1997) A comparative study of fungal populations in healthy and symptomatic twigs of Eucalyptus grandis in Uruguay. Mycol Res 101:1060-1064

Bloomberg WJ (1962a) Cytospora canker of poplar: factors influencing the development of the disease. Can J Bot 40:1271-1280

Bloomberg WJ (1962b) Cytospora canker of poplar: the moisture relations and anatomy of the host. Can J Bot 40:1281-1292

Callan BE (1998) Diseases of Populus in British Columbia: a diagnostic manual. Natural Resources Canada, Canadian Forest Service, Canada, $157 \mathrm{p}$

Colwell RK (2005) EstimateS: Statistical estimation of species richness and shared species from samples. Version 7.5. User's Guide and application published at: http://purl.oclc.org/estimates

Díaz L, Romero C (2001) Caracterización económica de las choperas en Castilla y León: Rentabilidad y turnos óptimos. I Simposio del Chopo, Zamora (Spain), pp 489-500

Fernández A, Herranz G (2004) El chopo (Populus sp.) Manual de Gestión Forestal Sostenible. Junta de Castilla y León, Valladolid, $53 \mathrm{p}$

Fisher PJ, Petrini O (1990) A comparative study of fungal endophytes in xylem and bark of Alnus species in England and Switzerland. Mycol Res 94:313-319 
Fritz RS (1999) Resistance of hybrid plants to herbivores: Genes, environment, or both? Ecology 80:382-391

Gardes M, Bruns TD (1993) ITS primers with enhanced specificity for basidiomycetes - application to the identification of mycorrhizae and rusts. Mol Ecol 2:113-118

Ginns JH (1986) Compendium of plant disease and decay fungi in Canada 1960-1980. Research Branch of Canada Agriculture Publications, Ottawa, $416 \mathrm{p}$

Korkama T, Pakkanen A, Pennanen T (2006) Ectomycorrhizal community structure varies among Norway spruce (Picea abies) clones. New Phytol 171:815-824

Lefèvre F, Légionnet A, de Vries S, Turok J (1998) Strategies for the conservation of a pioneer tree species, Populus nigra L., in Europe. Genet Sel Evol 30:181-196

Martín-García J, Espiga E, Pando V, Diez J (2011) Factors influencing endophytic communities in poplar plantations. Silva Fenn 45:169-180

Müller M, Kantola R, Kitunen V (1994) Combining sterol and fatty acid profiles for the characterization of fungi. Mycol Res 98:593603

Ninyerola M, Pons X, Roure JM (2005) Atlas Climático Digital de la Península Ibérica. Metodología y aplicaciones en bioclimatología y geobotánica. ISBN 932860-8-7. Universidad Autónoma de Barcelona, Bellaterra

Nungent LK, Sihanonth P, Thienhirun S, Whalley JS (2005) Biscogniauxia: a genus of latent invaders. Mycologist 19:40-44

Petrini O, Fisher PJ (1990) Occurrence of fungal endophytes in twigs of Salix fragilis and Quercus robur. Mycol Res 94:1077-1080

Pinon J (1984) Management of poplar diseases. Eur J For Pathol $14: 415-425$

Rossi V, Pattori E (2009) Inoculum reduction of Stemphylium vesicarium, the causal agent of brown spot of pear, through application of Trichoderma-based products. Biol Control 49:52-57

Santamaría O, Diez JJ (2005) Fungi in leaves, twigs and ítem bark of Populus tremula from northern Spain. For Pathol 35:95-104

Schulz B, Boyle C (2005) The endophytic continuum. Mycol Res 109:661-686

SIEMCALSA (1997) Mapa geológico y minero de Castilla y León, Escala 1:400.000. Memoria, CD-ROM y 3 mapas, Valladolid

Smulders MJM, Cottrell JE, Lefèvre F, van der Schoot J, Arens P, Vosman B, Tabbener HE, Grassi F, Fossati T, Castiglione S,
Krystufek V, Fluch S, Burg K, Vornam B, Pohl A, Gebhardt K, Alba N, Agúndez D, Maestro C, Notivol E, Volosyanchuk R, Pospísková $\mathrm{M}$, Bordács $\mathrm{S}$, Bovenschen J, van Dam BC, Koelewijn HP, Halfmaerten D, Ivens B, van Slycken J, Vanden Broeck A, Storme V, Boerjan W (2008) Structure of the genetic diversity in black poplar (Populus nigra L.) populations across European river systems: Consequences for conservation and restoration. For Ecol Manag 255:1388-1399

Sogonov MV, Castlebury LA, Rossman AY, Mejía LC, White JF (2008) Leaf-inhabiting genera of the Gnomoniaceae, Diaporthales. Stud Mycol 62:1-79

StafSoft I (2001) STATISTICA (data analysis software system), version 6.0. www.statsoft.com. In

Strobel GA (2003) Endophytes as sources of bioactive products. Microbes Infect 5:535-544

Tamura K, Dudley J, Nei M, Kumar S (2007) MEGA4: Molecular Evolutionary Genetics Analysis (MEGA) software version 4.0. Mol Biol Evol 24:1596-1599, Publication PDF at http://www. kumarlab.net/publications

Ter Braak CJF, Šmilauer P (2002) CANOCO Reference Manual and CanoDraw for Windows User's Guide: Software for Canonical Community Ordination (version 4.5). Microcomputer Power, Ithaca

Vainio EJ, Hantula J (2000) Direct analysis of wood-inhabiting fungi using denaturing gradient gel electrophoresis of amplified ribosomal DNA. Mycol Res 104:927-936

Vainio EJ, Korhonen K, Hantula J (1998) Genetic variation in Phlebiopsis gigantea as detected with random amplified microsatellite (RAMS) markers. Mycol Res 102:187-192

White T, Bruns T, Lee S, Taylor J (1990) Amplification and direct sequencing of fungal ribosomal RNA genes for phylogenetics. In: Innis MA, Gelfand DH, Sninsky JJ, White TJ (eds) PCR Protocols, a Guide to Methods and Applications. Academic, New York, pp 315-322

Whitham TG, Martinsen GD, Floate KD, Dungey HS, Potts BM, Keim P (1999) Plant hybrid zones affect biodiversity: tools for a genetic-based understanding of community structure. Ecology $80: 416-428$

Worrall JJ, Egeland L, Eager T, Mask RA, Johnson EW, Kemp PA, Shepperd WD (2008) Rapid mortality of Populus tremuloides in southwestern Colorado, USA. For Ecol Manag 255:686-696 